\title{
MENINGKATKAN KEMAMPUAN MENGENAL LAMBANG BILANGAN PADA ANAK USIA 4-5 TAHUN MELALUI PERMAINAN BALOK ANGKA
}

\author{
Agnes Dhear Nur Cahyani \\ Program Studi Pendidikan Guru Pendidikan Anak Usia Dini \\ Universitas Sebelas Maret \\ Surakarta, Indonesia
}

e-mail: agnesdhear12@gmail.com

\begin{abstract}
Abstrak
Rendahnya kemampuan mengenal lambang bilangan pada anak usia empat sampai lima tahun sering terjadi dan selalu menjadi topik hangat yang diperbincangkan setiap tahunnya oleh pendidik, orang tua, dan masyarakat. Dimana seharusnya anak usia empat sampai lima tahun sudah mampu mengenal lambang bilangan satu sampai sepuluh. Upaya yang dapat dilakukan untuk mengatasi permasalahan rendahnya kemampuan anak usia empat sampai lima tahun dalam mengenal lambang bilangan adalah dengan menggunakan permainan balok angka. Artikel ilmiah ini bertujuan untuk mengetahui cara meningkatkan kemampuan mengenal lambang bilangan pada anak usia empat sampai lima tahun melalui permainan balok angka. Jenis penelitian yang digunakan dalam artikel ilmiah ini adalah kualitatif-deskriptif. Metode yang digunakan dalam artikel ilmiah ini adalah kajian pustaka. Subjek dalam artikel ilmiah ini adalah anak usia empat sampai lima tahun. Berdasarkan sumber-sumber kajian pustaka yang dikumpulkan, didapatkan hasil bahwa cara mengenalkan lambang bilangan pada anak usia empat sampai lima tahun yang paling tepat adalah dengan menggunakan permainan balok angka. Hal ini sudah terbukti akurat dari hasil-hasil penelitian para peneliti yang menyatakan bahwa terdapat peningkatan yang signifikan dalam kemampuan mengenal lambang bilangan satu sampai sepuluh pada anak usia empat sampai lima tahun melalui permainan balok angka. Kesimpulan dari artikel ilmiah ini adalah terdapat empat langkah pelaksanaan permainan balok angka guna meningkatkan kemampuan mengenal lambang bilangan pada anak usia empat sampai lima tahun.
\end{abstract}

Kata-kata Kunci: lambang bilangan, anak usia 4-5 tahun, permainan balok angka

\begin{abstract}
The low ability to recognize number symbols in children aged four to five years often occurs and has always been a hot topic that is discussed annually by educators, parents, and the community. Where children aged four to five years should be able to recognize the symbol numbers from one to ten. Efforts that can be made to overcome the problem of the low ability of children aged four to five years in recognizing number symbols is to use the number block game. This scientific article aims to find out how to improve the ability to recognize number symbols in children aged four to five through number blocks. The type of research used in this scientific article is qualitative-descriptive. The method used in this scientific article is literature review. The subjects in this scientific article are children aged four to five years. Based on the literature review sources that were collected, it was found that the most appropriate way to introduce number symbols to children aged four to five years is to use the number block game. This has been proven to be accurate from the results of research by researchers which state that there is a significant increase in the ability to recognize the number symbols one to ten in children aged four to five through number blocks. The conclusion of this scientific article is that there are four steps to implement the number block game to improve the ability to recognize number symbols in children aged four to five years.
\end{abstract}

Keywords: symbol of numbers, children aged 4-5 years, a block game of numbers

Article History: received 28 May 2020, revised 21 October 2020, accepted 25 October 2020 


\section{PENDAHULUAN}

Anak usia dini merupakan seorang individu unik dalam rentang usia nol sampai enam tahun yang sedang berada di masa keemasannya dimana pertumbuhan dan perkembangannya mengalami ledakan yang luar biasa pesat. Salah satu aspek perkembangan yang memiliki pengaruh besar dalam kehidupan sehari-hari anak adalah aspek perkembangan kognitif karena hampir di semua aktivitas yang dilakukan oleh anak membutuhkan kemampuan berpikir (kognitif). Menurut (Filtri \& Sembiring, 2018), perkembangan kognitif adalah proses dimana individu dapat meningkatkan kemampuan dalam menggunakan pengetahuannya. Sedangkan (Gandana, Pranata, \& Danti, 2017) mendefiniskan kognitif sebagai suatu kemampuan berpikir seseorang dalam menghubungkan dan mempertimbangkan suatu pengetahuan terhadap suatu kejadian atau peristiwa sehingga orang tersebut memperoleh pengetahuan baru. Maka, dapat disimpulkan bahwa kognitif merupakan kemampuan berpikir seseorang dalam mengelola akal pikirannya untuk memperoleh pengetahuan-pengetahuan baru yang akan berguna bagi kehidupan mendatangnya.

Aspek perkembangan kognitif meliputi pemecahan masalah, berpikir logis, dan berpikir simbolik. Namun, artikel ilmiah ini lebih berfokus pada aspek perkembangan kognitif di bidang berpikir simbolik yaitu kemampuan mengenal lambang bilangan. Kemampuan mengenal lambang bilangan adalah suatu bentuk kesanggupan anak dalam mengenal dan mengetahui simbol yang melambangkan banyaknya benda (Syahrida, Wahyuningsih, \& Pudyaningtyas, 2017). Menurut (Susanto, 2011), kemampuan mengenal lambang bilangan anak usia empat sampai lima tahun meliputi : memahami lambang bilangan, menghubungkan konsep dengan lambang bilangan, memasangkan lambang bilangan dengan benda-benda sampai sepuluh (anak tidak diminta menulis).

Permasalahan rendahnya kemampuan mengenal lambang bilangan pada anak usia dini selalu menjadi topik hangat yang sering diperbincangkan baik di kalangan pendidik, orang tua maupun masyarakat. Yang mana pada aspek perkembangan kognitif di bidang berpikir simbolik seharusnya anak usia empat sampai lima tahun diharapkan sudah mampu membilang banyak benda dari satu sampai sepuluh, mengenal konsep bilangan, mengenal lambang bilangan, dan mengenal lambang huruf.

Ketidakmampuan anak usia empat sampai lima tahun dalam mengenal lambang bilangan biasanya sering ditunjukkan melalui beberapa kasus seperti anak yang masih terbolak-balik dalam melafalkan atau menyebutkan lambang bilangan, anak yang hanya mengetahui "satu, dua, tiga,..." saja tanpa mengetahui bentuk lambang bilangannya seperti apa, dan anak yang sudah mengenal beberapa lambang bilangan tetapi masih sering terbolak-balik atau salah dalam menulisnya. Bahkan ada juga anak yang diusianya seharusnya sudah mampu mengenal lambang bilangan tetapi sama sekali belum mengetahui bentuk lambang bilangan dan masih banyak lagi kasus atau permasalahan-permasalahan yang dialami oleh anak usia dini mengenai kemampuan mengenal lambang bilangan.

Dimana kemampuan mengenal lambang bilangan menjadi salah satu kemampuan yang sangat penting untuk dimiliki dan kuasai oleh anak. Sebab kemampuan mengenal lambang bilangan merupakan kemampuan dasar dalam bidang matematika yang kelak akan sangat berguna bagi kehidupan sehari-hari anak. Selain itu, kemampuan mengenal lambang bilangan juga dapat mempengaruhi kesiapan anak untuk melanjutkan ke jenjang pendidikan selanjutnya. Seperti yang telah diungkapkan oleh World Health Organization dalam penelitian longitudinal bahwa "early mathematics skills strongly predict later mathematics skills" yang artinya kemampuan matematika awal sangat menggambarkan kemampuan matematika dikemudian hari (Gandana et al., 2017).

Oleh sebab itu, banyak peneliti yang telah mencoba mencari solusi untuk membantu anak usia dini, khususnya anak usia empat sampai lima tahun dalam mengenal lambang bilangan. Seperti penelitian yang telah dilakukan oleh (Weni, 2018) dengan judul "Peningkatan Kemampuan 
Mengenal Lambang Bilangan Melalui Metode Proyek Dengan Menggunakan Media Kartu Pintar Siswa TK Pertiwi Banteran Kecamatan Wangon Kabupaten Banyumas". Meskipun penggunaan kartu pintar untuk meningkatkan kemampuan mengenal lambang bilangan sudah cukup baik. Tetapi, sangat disayangkan media kartu pintar yang digunakan hanya menggunakan kertas asturo warna-warni yang merupakan jenis kertas yang mudah rusak atau tidak tahan lama. Dimana hal tersebut tidak sesuai dengan salah satu syarat media pembelajaran menurut Badrun Zaman dalam (Multahada, 2016) yaitu awet, kuat dan tahan lama. Serta dikarenakan media yang digunakan terbuat dari kertas asturo mengharuskannya untuk membuatnya lagi ketika sudah rusak, sehingga media kartu pintar kurang efisien untuk membantu anak dalam mengenal lambang bilangan.

Selain itu, juga terdapat hasil penelitian lainnya yang telah dilakukan oleh (Dewi, Jampel, \& Tegeh, 2017) dengan judul "Pengaruh Metode Bernyanyi Berbantuan Media Microsoft Power Point Terhadap Kemampuan Mengenal Lambang Bilangan Pada Anak". Penggunaan media Microsoft Power Point juga sudah cukup baik karena telah mengikuti perkembangan zaman. Namun, sangat disayangkan penggunaan media Microsoft Power Point masih kurang optimal jika diterapkan pada anak usia dini. Apalagi anak usia dini masih berada ditahap berpikir konkret sehingga alangkah baiknya tetap memberikan media-media yang konkret atau nyata untuk anak.

Untuk menjawab permasalahan rendahnya kemampuan mengenal lambang bilangan pada anak usia empat sampai lima tahun serta mencari solusi yang lebih tepat dan efisien dibandingkan dengan hasil-hasil penelitian sebelumnya, maka penulis mengusulkan untuk menggunakan media balok angka yang dikemas ke dalam kegiatan bermain atau disebut dengan "Permainan Balok Angka". Alasan utama penulis mengusulkan Permainan Balok Angka guna mengatasi rendahnya kemampuan mengenal lambang bilangan pada anak usia empat sampai lima tahun adalah anak usia empat sampai lima tahun masih berada pada tahap bermain dan berpikir konkret. Maka, akan jauh lebih mudah dan efisien dalam mengenalkan lambang bilangan kepada anak usia empat sampai lima tahun melalui kegiatan bermain dengan menggunakan media yang konkret dan tahan lama seperti balok angka. Serta menurut Teori Piaget dalam (Hijriati, 2016) yang menyatakan bahwa pengetahuan dibangun melalui kegiatan atau aktivitas pembelajaran, juga menjadi alasan lainnya penulis memilih kegiatan permainan balok angka.

Balok angka merupakan salah satu media pembelajaran yang diciptakan langsung oleh Montessori pada tahun 1909 yang diperuntukkan untuk pembelajaran sensoris anak dalam mempelajari dasar-dasar aritmatika (Nursiatun, 2015). Bahkan Montessori sendiri sudah menguji keberhasilan media balok angka dalam membantu anak usia dini untuk lebih mengenal lambang bilangan. Oleh sebab itu, media balok angka menjadi salah satu media pembelajaran yang direkomendasikan oleh Montessori untuk membantu anak usia dini dalam mengenal lambang bilangan.

Definisi dari balok itu sendiri menurut (Hasendra, 2019) adalah bangun ruang tiga dimensi yang memiliki 6 sisi, 12 rusuk dan 8 titik sudut serta dibentuk oleh tiga pasang persegi atau persegi panjang, dengan paling tidak satu pasang diantaranya berukuran berbeda. Disisi lain, Bandura (Qholisya, 2019) menjelaskan pengertian dari balok angka sebagai suatu alat permainan edukatif yang terbuat dari potongan kayu atau plastik yang memiliki berbagai bentuk yang dimainkan dengan cara disusun atau disambungkan sesuai dengan imajinasinya sehingga membentuk atau menyerupai suatu bangunan. Lebih lanjut, (Yurnalisma \& Fatmawati, 2018) mengatakan bahwa media balok angka terdiri dari sepuluh unit yang terbuat dari kayu, setiap unit balok memiliki angka berbeda, media balok angka ini berbentuk persegi, yang dapat digunakan untuk mengembangkan kognitif anak usia dini. Jadi, dapat disimpulkan bahwa balok angka adalah media visual yang biasanya terbuat dari kayu atau bahan jenis plastik dengan bentuk tiga dimensi yang biasanya berbentuk persegi atau persegi panjang serta di setiap unit balok mewakili satu simbol angka guna meningkatkan kemampuan kognitif anak usia dini. 
Media balok angka yang dimaksudkan dalam penelitian ini adalah media balok angka beragam warna yang terbuat dari kayu. Balok angka ini berbentuk persegi yang dibagian tengahnya terdapat lubang kecil yang nantinya akan menjadi jalan untuk memasukkannya pada tiang kayu yang berbentuk bulat panjang. Serta disetiap sisinya terdapat simbol angka atau lambang bilangan berwarna hitam dimana setiap satu unit balok mewakili satu lambang bilangan. Maka dibutuhkan balok angka yang di setiap sisinya bersimbol angka satu sampai angka sepuluh, sebab anak usia empat sampai lima tahun diharapkan mampu mengenal dan membilang lambang bilangan satu sampai sepuluh.

Menurut Essa dalam (Pradana, 2016), terdapat tahapan dalam menggunakan balok angka untuk mengenalkan lambang bilangan pada anak usia dini sebagai berikut : (1) One-to-the one correspondences (korespondensi satu-satu). Cara dimana anak mulai memahami tentang konsep bilangan dengan cara mencocokan item yang sesuai dengan item lain. Pada tahap ini anak menyebutkan satu balok dengan menunjuk balok yang jumlahnya satu, menyebutkan dua balok dengan menunjuk balok yang jumlahnya dua, dan terus menerus sampai balok ke sepuluh. (2) Rote counting (menghafal bilangan) merupakan kemampuan mengulang angka-angka (membilang) yang akan membantu pemahaman anak tentang arti sebuah angka. (3) Rational counting (menghitung rasional). Dimana anak secara akurat menempel nama angka untuk serangkaian objek yang di hitung sehingga anak mengerti makna angka dan pengenalannya.

Dari ketiga tahapan mengenal lambang bilangan menggunakan balok angka tersebut dapat dijadikan sebagai landasan dalam menyusun kegiatan mengenal lambang bilangan satu sampai sepuluh menggunakan balok angka pada anak usia empat sampai lima tahun. Langkah pertama untuk mengenalkan lambang bilangan pada anak usia empat sampai lima tahun melalui permainan balok angka adalah mengangkat balok angka dengan simbol angka satu lalu anak diminta untuk mengambil satu buah balok angka sambil membilangnya dan untuk lambang bilangan seterusnya. Langkah kedua, mengajak anak menyebutkan simbol angka yang tertera pada balok angka dari satu sampai sepuluh. Langkah ketiga, anak diminta mengelompokkan balok angka berdasarkan simbol angka yang tertera pada balok angka. Kemudian langkah keempat dilakukan dengan mengajak anak berlomba-lomba bermain menyusun balok angka secara urut dari satu sampai sepuluh dengan cara memasukkannya ke dalam tiang kayu. Tujuan permainan balok angka dalam penelitian ini adalah untuk mengenalkan lambang bilangan satu sampai sepuluh dan menyusun balok angka secara urut mulai dari simbol angka satu sampai sepuluh.

Berdasarkan permasalahan yang diusung diatas, penulis tertarik untuk melakukan penelitian dengan judul "Meningkatkan Kemampuan Mengenal Lambang Bilangan Pada Anak Usia 4 - 5 Tahun Melalui Permainan Balok Angka : Kajian Pustaka". Dengan rumusan masalah bagaimana penggunaan Permainan Balok Angka dapat meningkatkan kemampuan mengenal lambang bilangan pada anak usia empat sampai lima tahun. Tujuan yang ingin dicapai dalam penelitian ini adalah untuk mengetahui cara meningkatkan kemampuan mengenal lambang bilangan pada anak usia empat sampai lima tahun melalui Permainan Balok Angka.

\section{METODE}

Artikel ilmiah ini merupakan jenis kualitatif-deskriptif. Jenis kualitatif merupakan pengumpulan data pada suatu latar alamiah dengan maksud menafsirkan fenomena yang terjadi dimana peneliti adalah sebagai instrument kunci, pengambilan sampel sumber data dilakukan secara purposive dan snowbaal, teknik pengumpulan dengan trianggulasi (gabungan), analisis data bersifat induktif atau kualitatif, dan hasil dari jenis kualitatif lebih menekankan makna dari pada generalisasi (Anggito \& Setiawan, 2018). Jenis kualitatif bersifat deskriptif dimana peneliti atau penulis harus mendeskripsikan permasalahan dan topik yang akan dituangkan dalam tulisan 
yang bersifat naratif. Maka, dapat disimpulkan bahwa jenis kualitatif-deskriptif adalah suatu metode pengolahan data yang dilakukan dengan cara menganalisis dan mendeskripsikan fenomena atau permasalahan yang berhubungan dengan objek penelitian dengan penyajian data secara lebih mendalam terhadap objek penelitian dan dalam bentuk tulisan yang bersifat naratif bukan dalam bentuk angka ataupun rumus.

Metode yang digunakan dalam menganalisis data pada artikel ilmiah ini adalah kajian pustaka. Kajian pustaka adalah salah satu metode yang dilakukan dengan mengumpulkan data dan informasi dari sumber-sumber bacaan yang bereputasi atau dapat dipercaya, seperti artikel ilmiah, jurnal, buku, e-book, dan lain sebagainya. Hal tersebut sesuai dengan pendapat (Purwono, 2010) dalam (Anggraini, 2015) yang menyatakan bahwa kajian pustaka (Literature Review) adalah segala usaha yang dilakukan oleh peneliti untuk menghimpun informasi yang relevan dengan topik atau masalah yang akan atau sedang diteliti. Pengumpulan data dan informasi dalam kajian pustaka dilakukan dengan cara membaca, memahami, mengkritik, dan mereview berbagai macam sumber-sumber bacaan yang bereputasi.

\section{HASIL DAN PEMBAHASAN}

Berdasarkan dari hasil sumber-sumber kajian pustaka baik berupa artikel ilmiah maupun buku yang dikumpulkan dan dianalisa oleh penulis didapatkan bahwa untuk mengenalkan lambang bilangan pada anak usia empat sampai lima tahun dapat dilakukan dengan melakukan Permainan Balok Angka. Dikarenakan dalam kegiatan permainan balok angka dirancang atau dikemas dalam bentuk permainan. Yang mana melalui permainan anak akan merasa lebih senang dan enjoy dalam melakukan kegiatan mengenal lambang bilangan. Serta pada dasarnya anak usia empat sampai lima tahun memang masih berada pada tahap bermain. Dimana saat melakukan kegiatan mengenal lambang bilangan anak merasa senang, maka apa yang dipelajari oleh anak hari itu akan bertahan lama dalam ingatan anak atau menjadi ingatan jangka panjang (long-term memory). Sehingga kegiatan permainan balok angka ini menjadi salah satu solusi yang tepat dan efisien dalam mengenalkan lambang bilangan pada anak usia empat sampai lima tahun.

Penggunaan media balok angka sudah sangat tepat untuk membantu anak usia empat sampai lima tahun mengenal lambang bilangan satu sampai sepuluh. Mengingat bahwa anak usia empat sampai lima tahun berada pada tahap berpikir konkret. Dimana akan lebih mudah mengajarkan anak menggunakan media konkret seperti balok angka. Media konkret dapat memberikan bentuk dan arti nyata yang sebelumnya hanya digambarkan dalam bentuk abstrak saja. Selain itu, media balok angka yang dikemas dalam bentuk permainan ini akan memberikan pengalaman langsung (hands on experince) kepada anak mengenai lambang bilangan satu sampai sepuluh. Sehingga anak dapat melihat secara langsung bentuk dari lambang bilangan satu sampai sepuluh dan konsep dari lambang bilangan itu sendiri. Ditambah lagi balok angka merupakan media pembelajaran yang sudah sesuai dengan syarat media pembelajaran yaitu aman, tahan lama, sesuai dengan tujuan dan fungsinya, multiguna, menggunakan bahan yang mudah dicari, mudah digunakan oleh anak serta fleksibel atau dapat digunakan secara individu maupun kelompok (Multahada, 2016).

Permainan balok angka memiliki fungsi dan kegunaan yang cukup banyak bagi anak diantaranya sebagai alat permainan edukatif yang menyenangkan bagi anak, membantu mengembangkan kreativitas anak dan membantu mengembangkan aspek perkembangan kognitif khususnya dalam bidang berpikir simbolik yaitu mengenal lambang bilangan dengan mudah, serta aspek perkembangan anak lainnya (seperti motorik halus). Selaras dengan pendapat (Sari \& Abdullah, 2015) yang menyatakan bahwa permainan balok angka dapat mengembangkan pemahaman mengenal lambang bilangan dengan cara yang menyenangkan sehingga dalam melaksanakan kegiatan anak akan merasa senang dan tanpa adanya suatu paksaan. 
Pelaksanaan kegiatan permainan balok angka guna mengenalkan lambang bilangan pada anak usia dini dilakukan dengan melalui empat langkah yaitu langkah pertama, guru mengangkat balok angka yang bersimbol angka satu lalu meminta anak mengambil satu buah balok angka bersimbol angka satu dan dilakukan seterusnya hingga balok angka yang bersimbol sepuluh. Pada langkah pertama ini bertujuan untuk mengenalkan konsep dari lambang bilangan itu sendiri. Dimana anak belajar memahami bahwa lambang bilangan satu memperlihatkan jumlah benda sebanyak satu buah, lambang bilangan dua memperlihatkan jumlah benda sebanyak dua buah, dan seterusnya. Sehingga anak tidak hanya mengetahui dan memahami bentuk lambang bilangannya saja tetapi diharapkan anak dapat mengetahui dan memahami konsep dari lambang bilangan itu sendiri.

Langkah kedua, guru mengajak anak menyebutkan simbol angka yang tertera pada balok angka dari satu sampai sepuluh. Pada langkah ini bertujuan untuk membantu anak menghafal dan mengingat simbol angka atau lambang bilangan yang ditunjukkan menggunakan balok angka. Yang mana guru menunjukkan dan memberitahukan bentuk dari lambang bilangan satu menggunakan balok angka bersimbol angka satu dan dilanjutkan dengan lambang bilangan lainnya. Namun, dalam menjelaskan bentuk dari lambang bilangan sebaiknya guru menghindari memberikan perumpamaan-perumpamaan yang dapat menimbulkan persepsi yang salah pada anak mengenai bentuk lambang bilangan. Misalnya, angka satu seperti lidi, angka dua seperti bebek, angka tiga seperti burung terbalik, angka empat seperti kursi terbalik, dan sebagainya. Sebab tidak semua bentuk benda yang dijadikan perumpamaan selalu berbentuk seperti lambang bilangan. Lebih jelasnya, tidak semua kursi berbentuk seperti angka empat melainkan ada yang berbentuk bulat, persegi, dan sebagainya. Maka, akan jauh lebih baik jika guru menunjukkan atau menggambarkan bentuk dari lambang bilangan sesuai dengan bentuk aslinya atau tidak dibuatbuat. Selain itu, pada langkah kedua ini guru juga dapat menguji apakah anak sudah mengingat bentuk lambang bilangan satu sampai sepuluh dengan cara mengacak urutannya.

Langkah ketiga, dilakukan dengan meminta anak untuk mengelompokkan balok angka sesuai dengan simbol angka yang tertera pada setiap sisi balok angka. Pada langkah ketiga ini diharapkan anak sudah berhasil pada langkah kedua sehingga anak sudah mengetahui dan mengingat bentuk lambang bilangan dari satu sampai sepuluh. Maka, pada langkah ketiga ini kemampuan anak dalam mengenal lambang bilangan satu sampai sepuluh semakin diperdalam dan diperkuat dengan tidak hanya mengajak anak untuk mengelompokkan balok angka saja tetapi anak diminta untuk membilang banyaknya balok angka di setiap bentuk lambang bilangannya. Lebih jelasnya, anak membilang banyaknya balok angka yang di setiap sisinya bersimbol angka satu dan seterusnya hingga balok angka yang bersimbol angka sepuluh.

Langkah terakhir atau langkah keempat, dilakukan dengan mengajak anak berlomba-lomba bermain menyusun balok angka secara urut dari satu sampai sepuluh dengan cara memasukkannya ke tiang kayu yang berbentuk bulat panjang. Pada langkah ini bertujuan untuk melihat perkembangan kemampuan mengenal lambang bilangan satu sampai sepuluh pada anak usia empat sampai lima tahun setelah melakukan langkah pertama, kedua dan ketiga. Saat melaksanakan langkah terakhir ini sebaiknya guru menginformasikan peraturan mainnya dan reward apa yang akan didapat oleh anak jika anak berhasil. Pemberian reward berguna untuk lebih membangkitkan semangat anak dalam mengikuti kegiatan lomba menyusun balok angka dari satu sampai sepuluh secara urut. Tentu saja pada tahap ini sangat diharapkan bahwa anak usia empat sampai lima tahun dapat menyusun balok angka dari angka satu sampai angka sepuluh secara urut. Serta dengan menunjukkan sikap percaya diri sebagai bentuk bahwa telah terjadi peningkatan kemampuan mengenal lambang bilangan satu sampai sepuluh pada anak usia empat sampai lima tahun melalui permainan balok angka.

Permainan balok angka memiliki kelebihan yang membuat permainan ini menjadi salah satu treatment yang tepat untuk diberikan kepada anak usia empat sampai lima tahun dalam mengenal lambang bilangan. Kelebihan yang terdapat pada permainan balok angka ini diantaranya adalah 
anak dapat belajar mengenal konsep bilangan dan lambang bilangan menggunakan benda konkret, anak merasa senang selama kegiatan mengenal lambang bilangan, anak dapat belajar menghitung permulaan, anak menjadi mengenal bentuk tiga dimensi (balok), anak dapat belajar mengenai pengklasifikasian atau pengelompokkan berdasarkan bentuk simbol angka pada balok angka, anak dapat menghubungkan banyaknya benda dengan balok angka, serta dapat menyusun balok angka secara urut. Selain itu, tidak dipungkiri pula bahwa permainan balok angka juga memiliki kekurangan yaitu dapat membahayakan keamanan dan keselamatan anak jika tidak didampingi oleh orang dewasa. Dikarenakan permainan balok angka ini menggunakan media balok angka yang biasanya terbuat dari kayu. Jika anak tanpa pengawasan dari orang dewasa melakukan tindakan melempar balok angka, maka akan membahayakan diri anak atau orang di sekitarnya. Oleh karena itu, dalam melakukan permainan balok angka anak-anak harus didampingi oleh orang dewasa baik itu guru maupun orang tua.

Berdasarkan hasil dari pengumpulan dan penganalisaan sumber-sumber kajian pustaka yang telah dilakukan oleh penulis, menyatakan bahwa baik penggunaan media balok angka yang dikemas dalam bentuk permainan ataupun tidak, keduanya memiliki pengaruh terhadap keberhasilan anak usia dini khususnya anak usia empat sampai lima tahun dalam kemampuan mengenal lambang bilangan satu sampai sepuluh. Hal ini dibuktikan pada hasil penelitian yang telah dilakukan oleh (Nursa'idah, 2016) dengan judul "Mengembangkan Kemampuan Mengenal Angka 1-10 Menggunakan Media Balok Angka di Kelompok A TK Kusuma Mulia Al Falah Kabupaten Kediri" yang menunjukkan adanya peningkatan sebesar $59,3 \%$ setelah diberikan treatment (layanan) dengan menggunakan media balok angka dalam kegiatan mengenal lambang bilangan satu sampai sepuluh. Serta juga dibuktikan oleh (Sari \& Abdullah, 2015) dalam penelitiannya yang menunjukkan bahwa adanya peningkatan yang signifikan setelah anak kelompok $\mathrm{A}$ diberikan treatment dengan menggunakan permainan balok angka. Peningkatan kemampuan mengenal lambang bilangan satu sampai sepuluh pada anak usia empat sampai lima tahun ditunjukkan dengan adanya kemampuan yang telah dicapai oleh anak seperti anak sudah mampu menunjuk lambang bilangan satu sampai sepuluh, mampu meniru lambang bilangan satu sampai sepuluh, dan mampu menghubungkan atau memasangkan lambang bilangan dengan benda satu sampai sepuluh. Jadi, jika anak sudah mencapai indikator-indikator tersebut maka dapat dikatakan anak sudah mampu mengenal lambang bilangan satu sampai sepuluh.

Keberhasilan pengenalan lambang bilangan pada anak usia empat sampai lima tahun melalui permainan balok angka dipengaruhi oleh faktor internal dan faktor eksternal. Faktor internal nya yaitu kecerdasan anak, karena kecerdasan sangat penting dalam proses pembelajaran. Tingkat kecerdasan anak dapat mempengaruhi daya tangkap anak selama kegiatan pembelajaran. Jika anak memiliki daya tangkap yang tinggi, maka pengenalan lambang bilangan yang diajarkan kepadanya akan lebih mudah tersampaikan. Sebaliknya, jika anak memiliki daya tangkap yang cukup rendah, maka pengenalan lambang bilangan yang diajarkan kepada anak akan sulit tersampaikan. Hal ini sesuai dengan pendapat (Masliani, 2018) bahwa tingkat intelegensi seorang individu memiliki potensi besar untuk berprestasi, lebih mampu mengikuti materi yang diajarkan, dan berpeluang besar dalam mencapai keberhasilan. Sedangkan untuk faktor eksternal yang dapat mempengaruhi keberhasilan pengenalan lambang bilangan pada anak usia empat sampai lima tahun melalui permainan balok angka adalah tingkat keterampilan dan kreativitas pendidik. Jika seorang pendidik mampu menciptakan inovasi-inovasi dalam pengembangan media pembelajaran, dapat memanfaatkan media yang sudah ada, serta mampu menciptakan suasana pembelajaran yang menyenangkan bagi anak. Maka, anak akan lebih mudah dalam menyerap materi pembelajaran yang diajarkan oleh guru serta anak juga akan merasa senang dan nyaman selama melakukan kegiatan pembelajaran sehingga tujuan pembelajaran dapat tercapai.

Meskipun dalam hasil-hasil penelitian yang telah dikumpulkan dan dianalisa oleh penulis menyatakan bahwa dalam pengenalan lambang bilangan satu sampai sepuluh pada anak usia 
empat sampai lima tahun dapat dilakukan dengan menggunakan permainan balok angka maupun hanya menggunakan media balok angka saja. Namun, penggunaan permainan balok angka lebih memudahkan anak usia empat sampai lima tahun dalam mengenal lambang bilangan daripada hanya menggunakan media balok angka saja. Karena melalui kegiatan permainan, anak akan berada pada kondisi mood yang baik yaitu anak merasa senang dan enjoy. Dengan mood anak yang baik ini akan mempermudah guru dalam mengajarkan materi pembelajaran kepada anak, sehingga materi yang diajarkan kepada anak dapat tersampaikan secara optimal dan dan menjadi long-term memory (ingatan jangka panjang). Hal ini sesuai dengan pendapat (Wijaya, 2016) yaitu untuk mencapai kualitas pembelajaran yang baik dan kegiatan pembelajaran yang efektif bagi anak usia dini dapat dilakukan dengan menggunakan kegiatan permainan atau metode bermain. Maka, untuk mengenalkan lambang bilangan pada anak lebih tepat dengan menggunakan permainan balok angka daripada hanya menggunakan media balok angka saja.

\section{PENUTUP}

Berdasarkan hasil dan pembahasan, maka dapat disimpulkan bahwa penggunaan permainan balok angka dapat meningkatkan kemampuan mengenal lambang bilangan pada anak usia empat sampai lima tahun dengan melakukan empat langkah pelaksanaan permainan balok angka yaitu (1) Mengangkat balok angka dengan simbol angka satu lalu anak diminta untuk mengambil satu buah balok angka sambil membilangnya dan dilanjutkan dengan lambang bilangan seterusnya; (2) Mengajak anak menyebutkan simbol angka yang tertera pada balok angka dari satu sampai sepuluh; (3) Anak diminta mengelompokkan balok angka berdasarkan simbol angka yang tertera pada balok angka; dan (4) Mengajak anak berlomba-lomba bermain menyusun balok angka secara urut dari satu sampai sepuluh dengan cara memasukkannya ke dalam tiang kayu. Hal ini dibuktikan dari hasil penelitian para peneliti yang telah dikumpulkan dan dianalisa oleh penulis, dimana hasil dari penelitian-penelitian tersebut membuktikan adanya peningkatan yang signifikan dalam kemampuan mengenal lambang bilangan satu sampai sepuluh pada anak usia empat sampai lima tahun melalui permainan balok angka. Adapun saran yang dapat diberikan agar artikel ilmiah ini dapat memberikan manfaat. Saran yang ditujukan kepada pihak sekolah yaitu diharapkan pihak sekolah mampu menyediakan media balok angka di lembaga Pendidikan Anak Usia Dini nya agar para pendidiknya dapat menjadikan media balok angka sebagai media pembelajaran untuk mengenalkan konsep awal lambang bilangan kepada anak usia dini karena anak usia dini masih berada pada tahap berpikir konkret. Selain itu, agar anak tertarik dengan media balok angka maka disarankan agar para pendidik atau guru menciptakan suasana dan lingkungan pembelajaran yang menyenangkan bagi anak dengan mengemas kegiatan balok angka menjadi sebuah permainan yang menyenangkan dan menarik minat anak. Saran juga ditujukan kepada peneliti lain yaitu dalam melakukan kajian pustaka atau penelitian yang serupa diharapkan peneliti dapat melakukan kajian pustaka atau penelitian yang lebih mendalam lagi agar hasil yang diberikan dapat lebih akurat dan dapat menemukan solusi atau cara-cara lain dalam mengenalkan lambang bilangan kepada anak usia dini. Maka, hal yang dapat dilakukan oleh peneliti lain adalah melakukan kajian pustaka dengan menggunakan sumber-sumber yang lebih banyak dan akurat serta juga melakukan penelitian secara langsung dan mengkajinya menggunakan sumber-sumber penelitian lainnya yang bereputasi tinggi.

\section{DAFTAR PUSTAKA}

Anggito, A., \& Setiawan, J. (2018). Metodologi Penelitian Kualitatif (E. D. Lestari, Ed.). Retrieved from

https://books.google.co.id/books?hl=en\&lr=\&id=59V8DwAAQBAJ\&oi=fnd\&pg=PP1\&dq=jurn al+pengertian+jenis+penelitian+kualitatif+deskriptif\&ots=5GhCrzcsEp\&sig=unLy_soopjSnZ8 
kKKNqcqXClefA\&redir_esc=y\#v=onepage \&q\&f=false

Anggraini, G. (2015). Kajian Pustaka (Literature Review) (Vol. 6, pp. 1-13). Vol. 6, pp. 1-13. https://doi.org/10.1017/CBO9781107415324.004

Dewi, N. L. P. A., Jampel, I. N., \& Tegeh, I. M. (2017). Microsoft Power Point Terhadap Kemampuan Mengenal Lambang Bilangan Pada Anak. E-Journal Pendidikan Anak Usia Dini Universitas Pendidikan Ganesha, 5(1), 33-44. Retrieved from https://ejournal.undiksha.ac.id/index.php/JJPAUD/article/view/11070

Filtri, H., \& Sembiring, A. K. (2018). Perkembangan Kognitif Anak Usia 5-6 Tahun di Tinjau dari Tingkat Pendidikan Ibu Di Paud Kasih Ibu Kecamatan Rumbai. PAUD Lectura: Jurnal Pendidikan Anak Usia Dini, 1(2), 169-178. https://doi.org/10.31849/paudlectura.v1i2.1179

Gandana, G., Pranata, O. H., \& Danti, T. Y. (2017). Peningkatan Kemampuan Mengenal Lambang Bilangan 1-10 melalui Media Balok Cuisenaire pada Anak Usia 4-5 Tahun di TK AtToyyibah. Jurnal Paud Agapedia, 1(1), 92-105. Retrieved from https://ejournal.upi.edu/index.php/agapedia/article/viewFile/7160/4760

Hasendra, A. (2019). Penggunaan Balok Angka Sebagai Media Pembelajaran Untuk Meningkatkan Kemampuan Kognitif Anak Di Taman Kanak-Kanak Pertiwi Kota Jambi. Jurnal Literasiologi, 2(2), 64-80. https://doi.org/https://doi.org/10.47783/literasiologi.v2i2.42

Hijriati. (2016). Tahapan perkembangan kognitif pada masa early childhood. Jurnal Pendidikan Anak, 1(2), 1-17. Retrieved from http://103.107.187.25/index.php/bunayya/article/download/2034/1506

Masliani, S. (2018). Peningkatan Intelegensi Dan Hasil Belajar Siswa Melalui Pembelajaran Fungsi Logaritma Menggunakan Model Quantum Learning. MaPan : Jurnal Matematika Dan Pembelajaran, 6(1), 70-81. https://doi.org/10.24252/mapan.2018v6n1a7

Multahada, A. (2016). Variasi Penggunaan Media Pembelajaran Dalam Mengajarkan Calistung Pada Anak Usia 5-6 Tahun di RA Babul Jannah Sambas (UIN Sunan Kalijaga Yogyakarta). Retrieved from http://digilib.uin-suka.ac.id/22618/

Nursa'idah. (2016). Menggunakan Media Balok Angka di Kelompok A TK Kusuma Mulia Al-Falah Kabupaten Kediri. Universitas Nusantara PGRI Kediri, 1-11. Retrieved from http://simki.unpkediri.ac.id/mahasiswa/file_artikel/2016/12.1.01.11.0419.pdf

Nursiatun. (2015). Mengembangkan Kemampuan Kognitif Dalam Mengurutkan Angka 1-10 Menggunakan Metode Bermain Menyusun Balok-Balok Angka Pada Anak Kelompok A Tk Baitussalam Tulungagung. Universitas Nusantara PGRI Kediri, 01(08), 1-12. Retrieved from http://simki.unpkediri.ac.id/mahasiswa/file_artikel/2015/11.1.01.11.0129.pdf

Pradana, P. H. (2016). Pengaruh Permainan Balok Angka Terhadap Kemampuan Mengenal Lambang Bilangan Pada Anak Usia Dini. Jurnal Paud Tambusai, 2, 18-25. https://doi.org/https://doi.org/10.31004/obsesi.v2i2.38

Qholisya, N. (2019). Pengaruh Permainan Balok Angka Terhadap Kemampuan Berhitung Pada Anak Tk B Bustaannur (Universitas Medan Area Medan). Retrieved from http://repository.uma.ac.id:8081/bitstream/123456789/10799/1/148600354 - Nur Qholisya Fulltext.pdf

Sari, D., \& Abdullah, M. (2015). Pengaruh Permainan Balok Angka Terhadap Kemampuan Mengenal Lambang Bilangan 1-10 Pada Anak Kelompok A. PAUD Teratai, 1-7. Retrieved from https://jurnalmahasiswa.unesa.ac.id/index.php/paud-teratai/article/view/14470

Susanto, A. (2011). Perkembangan Anak Usia Dini: Pengantar Dalam Berbagai Aspeknya (Pertama). Retrieved from https://books.google.co.id/books?id=0qRPDwAAQBAJ\&pg=PA100\&lpg=PA100\&dq=tiga+tah $a p+d a l a m+$ pengenalan+lambang+bilangan+pada+anak+usia+dini+yaitu+tahap+penguasaan 
+konsep,+tahap+transisi,+dan+tahap+lambang\&source=bl\&ots=ewAXuMOymk\&sig=ACfU3 UOKA0aU8txAn7p3laE0I

Syahrida, U., Wahyuningsih, S., \& Pudyaningtyas, A. R. (2017). Lambang Bilangan Melalui Media Kartu Angka Bergambar (Pada Anak Kelompok A Raudhatl Athfal Masyithoh) Plumpung Cawas Klaten Simbol-Simbol. FKIP UNS Journal Systems, 5(1), 1-11. Retrieved from https://jurnal.fkip.uns.ac.id/index.php/paud/issue/download/715/66

Weni, R. P. (2018). Peningkatan Kemampuan Mengenal Lambang Bilangan Melalui Metode Proyek Dengan Media Kartu Pintar Siswa TK Pertiwi Banteran Kecamatan Wangon Kabupaten Banyumas. Aș-Șibyān: Jurnal Pendidikan Anak Usia Dini.

Wijaya, I. D. (2016). Deskripsi Proses Pembelajaran di Taman Kanak-Kanak. Calyptra: Jurnal Ilmiah Mahasiswa Universitas Surabaya, 5(1), 1-15. Retrieved from http://id. portalgaruda.org/article. php?article=440703\&val=5455

Yurnalisma, \& Fatmawati. (2018). Meningkatkan Kemampuan Mengenal Lambang Bilangan Satu Sampai Lima Melalui Media Balok Angka bagi Anak Tunagrahita Sedang Kelas VII di SL B N 1 Padang. Jurnal Penelitian Pendidikan Kebutuhan Khusus, 6, 156-164. Retrieved from http://ejournal.unp.ac.id/index.php/jupekhu/article/view/101682 